\title{
Domestication of Alfalfa Leaf-cutter
}

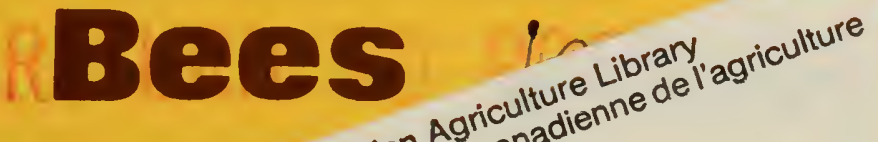

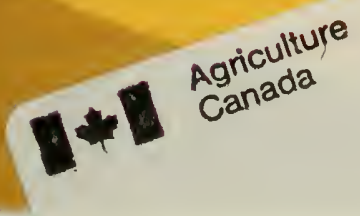

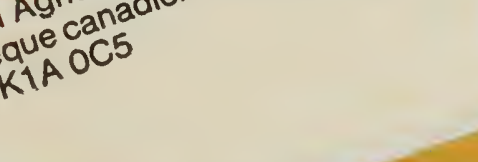

630.4

C212

P 1313

1967

c. 3 Canadian aue cane
Bibliothe K $1 \mathrm{~A} \mathrm{OC}^{5}$
Ottawia

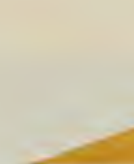




\section{BEES TO POLLINATE ALFALFA}

Alfalfa leaf-cutter bees are pollinators that can be easily domesticated. Because they are gregarious and thrive in man-made nests, you can protect them from bad weather and from enemies, and rapidly increase their numbers. You can incubate them so that they will emerge as adults when the alfalfa is beginning to bloom. In this way they will pollinate the alfalfa in time for seed to mature before frost and in time for harvest before bad weather spoils the crop.

To pollinate large acreages of alfalfa, import these valuable bees and build up large numbers of them as quickly as possible.

- Incubate them so that they will emerge when the alfalfa is beginning to bloom.

- Provide them with tunnels to use as homes.

- Set the homes beside their food and leaf-cutting source-alfalfa.

- Proteci them from their enemies while they are in the field.

- Bring them in when nesting activity is over and store them temporarily in a dry, unheated room.

- After the cells have dried and before temperatures outside drop below $0^{\circ} \mathrm{F}$, remove the cells from the hives and store them in a room at abour $40^{\circ} \mathrm{F}$.

Cover photograph. Female alfalfa leaf-cutter bee with a leaf cutting tucked beneath ber body. 


\title{
Domestication of Alfalfa Leaf-cutter Bees
}

\author{
G. A. Hobbs \\ Re search Station, Lethbridge, Alberta
}

Farmers in warm, dry regions of Canada have a good chance to regain domestic and export markets for alfalfa seed. This can be done because we now have a pollinator we can manage-the alfalfa leaf-cutter bee (Megachile rotundata $F$.). It was accidentally introduced into the United States from the Mediterranean region and has since spread across that country. It has not spread northward into Canada because it cannot survive naturally in our climate.

As it does not forage until the air temperature reaches $70^{\circ} \mathrm{F}$, it should be used only in regions of Canada that have enough warm weather to satisfy its needs. Minimum requirements are 350 bours with temperatures above $69^{\circ} \mathrm{F}$ during the pollinating period of alfalfa (the period beginning the day the alfalfa begins to bloom and ending the day after which flowers that have tripped will not have time to set mature seed before frost). In southern Alberta, this period usually begins about June 20 and ends about August 5 . Areas of Western Canada with 350 or more daylight hours with temperatures above $69^{\circ}$ (flying hours) between 7 a.m. and 8 p.m. during the pollinating period are the shaded areas on the map in Figure 1. The average numbers of hours per year for 1961-1966 are shown beside each Department of Transport Weather Station on the map. The data was compiled by the Department of Transport, Toronto, Ontario. Check the figures beside the weather station nearest your farm. Your chances of growing alfalfa seed successfully with the help of the alfalfa leaf-cutter bee will depend on how many flying hours there are in your region compared with the numbers beside stations in the shaded areas.

This bee will become the most important pollinator of alfalfa in Canada because:

- It thrives in man-made nests, which you can move indoors for the winter to protect the larvae from the cold. In the spring you can incubate the larvae so that they will emerge as adults when the alfalfa blooms.

- It is gregarious. Thousands of females work side by side to fill all the nests (tunnels) with cells.

- It trips and cross-pollinates nearly every alfalfa flower it visits. 


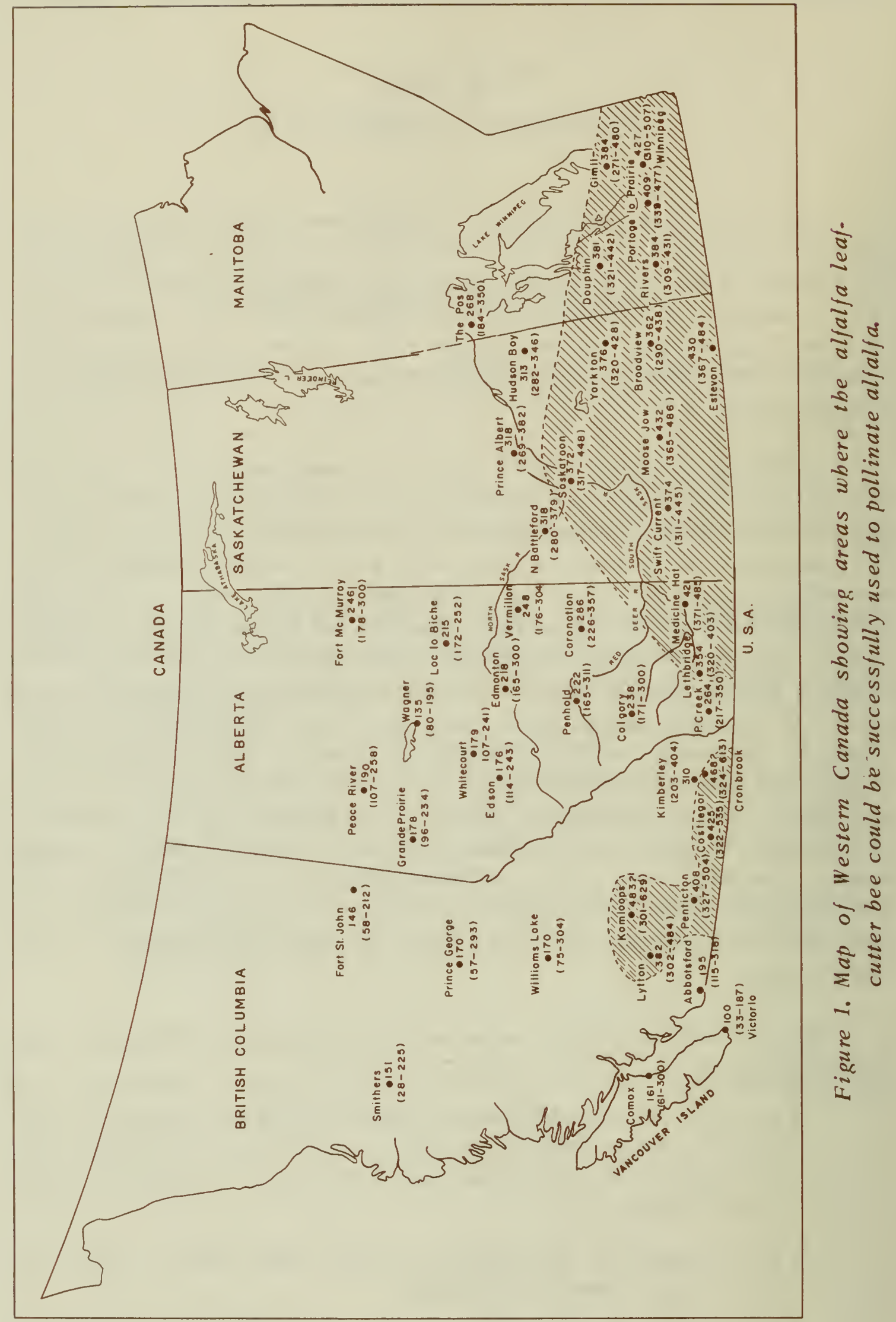


- It flies no farther for food than is necessary and can therefore be used to pollinate alfalfa in a particular field.

- You can protect it from predators, parasites, and disease.

Before this bee became available, certain species of native leafcutter bees and bumblebees were the important pollinators of alfalfa. But the yield of seed was uncertain because the native bees were hard to manage and could not be protected from weather and natural enemies.

The native leaf-cutter bees that were valuable pollinators tunneled under clumps of grass on the prairie or into rotting logs in the woodland, but did not nest in man-made tunnels. The important bumblebee pollinators built nests in man-made hives, but managing them was complicated and time-consuming. Alfalfa seed fields had to be alongside prairie or woodland, where the bees nested, and there were seldom enough bees to pollinate a 20-acre field. By managing the alfalfa leaf-cutter bee properly, you can produce enough bees to pollinate large acreages of alfalfa. Fields may be of any size or shape. You can take the pollinators to fields of alfalfa just as you take honey bees to fields of sweet clover or alsike.

\section{LIFE HISTORY}

All leaf-cutter bees are solitary bees but the alfalfa leaf-cutter bee is the only one that is also gregarious. It does not live in a colony like the honey bee or bumblebee; it lives alone but very close to its own kind. This urge to live close to neighbors is one of the two main reasons why it has been possible to domesticate it. The other reason is that it will live in man-made dwellings. Although some of our native leaf-cutter bees will live in man-made dwellings, they are not gregarious and therefore will not stay where they are put.

The male usually emerges before the female. When the female alfalfa leaf-cutter bee emerges from her cocoon, she mates, chooses her nesting site, and then begins to make cells and provision them. She obtains no help from the male or from other females. She makes cells with cuttings from leaves or petals, as she has no glands that produce wax. After making the walls with oblong leaf cuttings, she fills the cell about two thirds full with pollen and honey and then lays an egg, which floats on the honey. She caps the cell with circular leaf cuttings. She builds cells end to end in the tunnel, beginning at the far end and finishing near the entrance (Figure 2). She fills the tunnel entrance with closely packed, circular leaf 

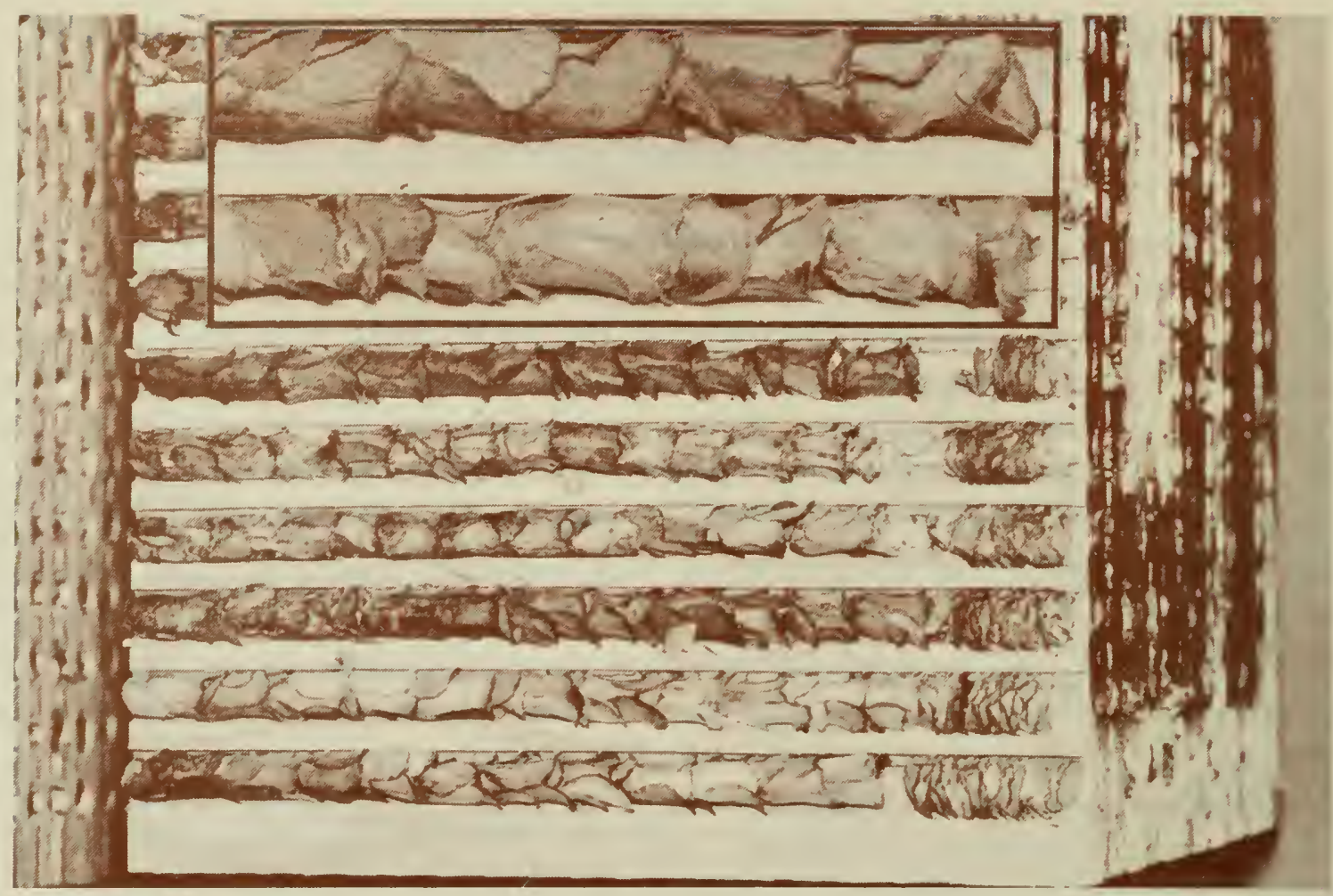

Figure 2. Exposed nests in tunnels made with grooved boards. Photograph shows cells made of leaf cuttings (top) and petals (bottom).

cuttings. When taken from the tunnel, the cylinder of cells often seems to be an indivisible unit because the walls of adjoining cells overlap.

The egg hatches in its cell, and the larva feeds on the honey and pollen. The larva sheds its skin several times and is full-grown when all the food is gone. Until it is full grown it has a blind gut and, therefore, cannot defecate and contaminate its food and quarters. When it has eaten all its food, it places its tawny fecal pellets beneath the cap at the head of the cell and separates itself from this source of contamination by spinning a cocoon. It spends the winter in the cocoon in this stage of development-a full-grown larva.

During the warm weather the next spring and early summer, or after it has been taken out of cold storage and placed in an incubator, it changes to a pupa within the cocoon in the cell. At first, the pupa is completely white; later the eyes turn pink, then black; then the whole pupa turns grayish black. A week or so later, the adult bee emerges.

Males emerge first. Most of them emerge before the first females appear. 
As soon as the females emerge from their cocoons, the males mate with them. Males mate many times but females only once. The males spend the rest of their lives chasing females, resting, or gathering nectar. They are not very effective as pollinators because they often take the nectar from alfalfa without tripping the flower. Males have thick yellow hair on their faces and have straight-sided square-ended abdomens with no conspicuous rows of hairs underneath. Females have gray hair on their faces and have oval abdomens with pointed ends; the undersides are covered with parallel rows of conspicuous whitish hairs, which serve to carry pollen.

These bees will not attack you. You may watch from inches away as thousands of females make cells, provision them, and lay eggs in them in the tunnels. If you are accidentally stung by a female, it is not much worse than being pricked with a hot needle. The males cannot sting.

The methods and equipment described in this publication will enable you to care for millions of these leaf-cutter bees.

\section{OBTAINING BEES AND HANDLING THEM ON ARRIVAL}

To import the bees, you must obtain a permit from the Plant Protection Division, Production and Marketing Branch, Canada Department of Agriculture, Central Experimental Farm, Ottawa, Ontario. The reason for this permit is to prevent the introduction of injurious insects and diseases. The bees must be imported as larvae in loose cells, which are easily inspected at ports of entry. Officers of the Plant Protection Division will refuse entry of cells that are still in nests. There are no import duties on alfalfa leaf-cutter bees, but you must still clear them through Canadian Customs. To do this, you should engage a Customs Broker or complete a B.1 entry form. If you hire a Customs Broker, choose one in a town where there are offices of both the Plant Protection Division and Canada Customs, and have the bees shipped in bond to that town. Give the Customs Broker power of attorney so that he can quickly clear your bees through customs and send them to you. Otherwise, they might be harmed by being left too long in a warm building.

A list of people who raise and sell alfalfa leaf-cutter bees where they thrive naturally may be obtained from the Research Station, Lethbridge, Alberta. In 1965-1966 the bees (larvae in cocoons) were selling for $\$ 100$ per American gallon containing about 10,000 cells. Therefore, each cell costs about one cent. At present there are few Canadian sources of alfalfa leaf-cutter bees, but there should be plenty of them after the 1969 season. 
When you receive the bees, put them in a cool, dry place that you can maintain at about $40^{\circ} \mathrm{F}$. If a cool, damp place such as a root cellar is used, prevent the cells from absorbing moisture and becoming moldy by storing them in airtight containers. The dormant larvae need little oxygen, but you should open the containers about once a month and fan fresh air into them before resealing them to make sure that the larvae do not suffocate. If mold develops, you can stop it from developing further by removing the cells from the container and spreading them out in a dry, cool room and allowing them to dry until the leaves around the cocoons become brittle. Or, you can destroy the mold without harming the larvae by soaking the cells for 5 minutes in a solution of equal parts of water and household bleach and then dusting them with 50 or 65 percent captan. Allow the cells to dry in a cool, dry room before retuming them to cold storage. Then replace them in the container, seal it, and return it to the $40^{\circ} \mathrm{F}$ room.

\section{MAKING EQUIPMENT}

You can mass-produce nests by grooving 3/8-inch $\mathrm{K}_{3}$ Particleboard with custom-tooled blades that have semicircular teeth made to fit a planer or jointer. Blades that are made to fit a 12-inch planer will cut 30 parallel, semicircular grooves $1 / 8$ inch deep, $1 / 4$ inch wide, and $1 / 8$ inch apart; blades that are made to fit a 6 -inch jointer will cut 15 grooves. If you use a jointer, you may cut the boards twice the width of the blade and run them through twice. Groove the Particleboard on both sides, cut it into pieces $43 / 8$ inches long, and stack them vertically so that the grooves form tunnels (nests), each $1 / 4$ inch in diameter. A planer that is self-fed and self-pressurized is far more efficient for grooving boards than a jointer that is handfed and hand-pressurized.

To obtain as many nests as possible from an 8- by 4 -foot sheet of Particleboard cut into easily worked pieces, first cut it across into two pieces 46 and 50 inches long, then cut each of these into four pieces approximately $117 / 8$ inches wide (the exact size will depend on the width of the saw cut). The table of a 12-inch planer may be reduced in width to $117 / 8$ inches by spot-welding an 1/8-inch welding rod along one side so that there is no play when the boards are being grooved. Groove a proportionate number of pieces on one side only, to provide the two end pieces in each hive; groove the remaining pieces on both sides so that they form tunnels with the end pieces and with each other when stacked.

\section{Hives}

Hives are designed so that as many hives as possible can be stacked in 8 - by 4- by 6-foot shelters; each contains about 3000 nests (Figure 3). 


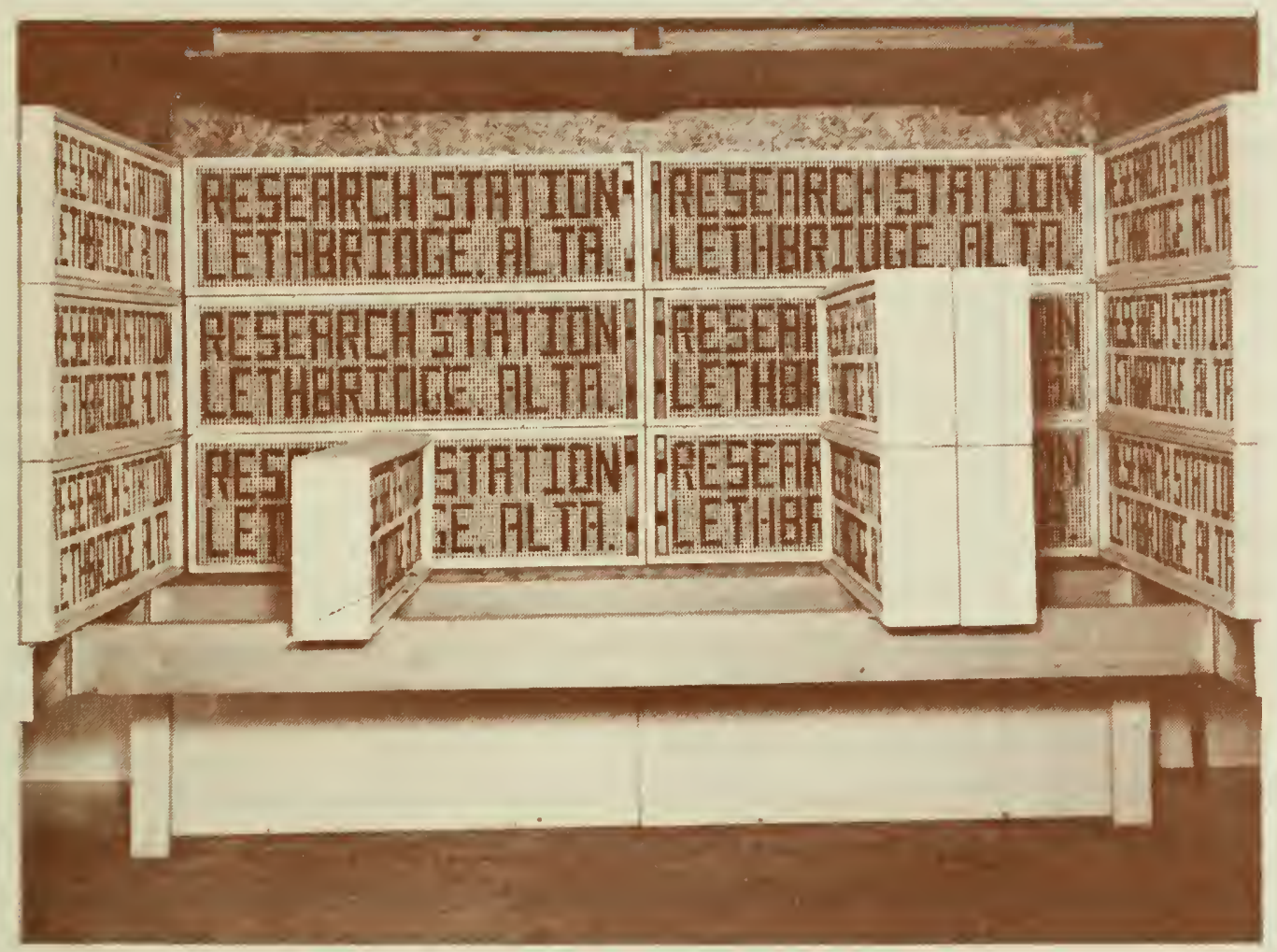

Figure 3. Shelter with hives and incubation trays in position.

After the strips of wood have been nailed along the inside front edges of the top and bottom of a hive, stack the grooved boards against the strips. Remove the sawdust and nail the back on the hive. Align all the grooved boards to form tunnels by shaking and pressing them into position, then press two steel springs into the 1-inch space between an end board and the end of the hive to supply the pressure needed to hold the grooved boards firmly together (Figures 3 and 4). The springs will also allow for the expansion that takes place when the tunnels are being filled with moist leaves, honey, and pollen. Plans are in Figure 4.

Paint the faces of your hives white and stencil your name or initials on them in blue or black. This helps the bees find their own nests and reduces the risk of having your hives stolen. The bees nest first in the tunnels in the dark letters; if the letters are spread evenly across the hive, the bees will make nests evenly across it. Be sure to allow enough time for the paint to dry thoroughly before the bees begin to nest in the bives.

Shelters

Sizes of shelters and incubators are governed by the standard 8by 4 -foot sheet of composition or laminated board (Figure 3). Three sheets of 5/16-inch Aspenite are used to make a shelter. One sheet becomes the 


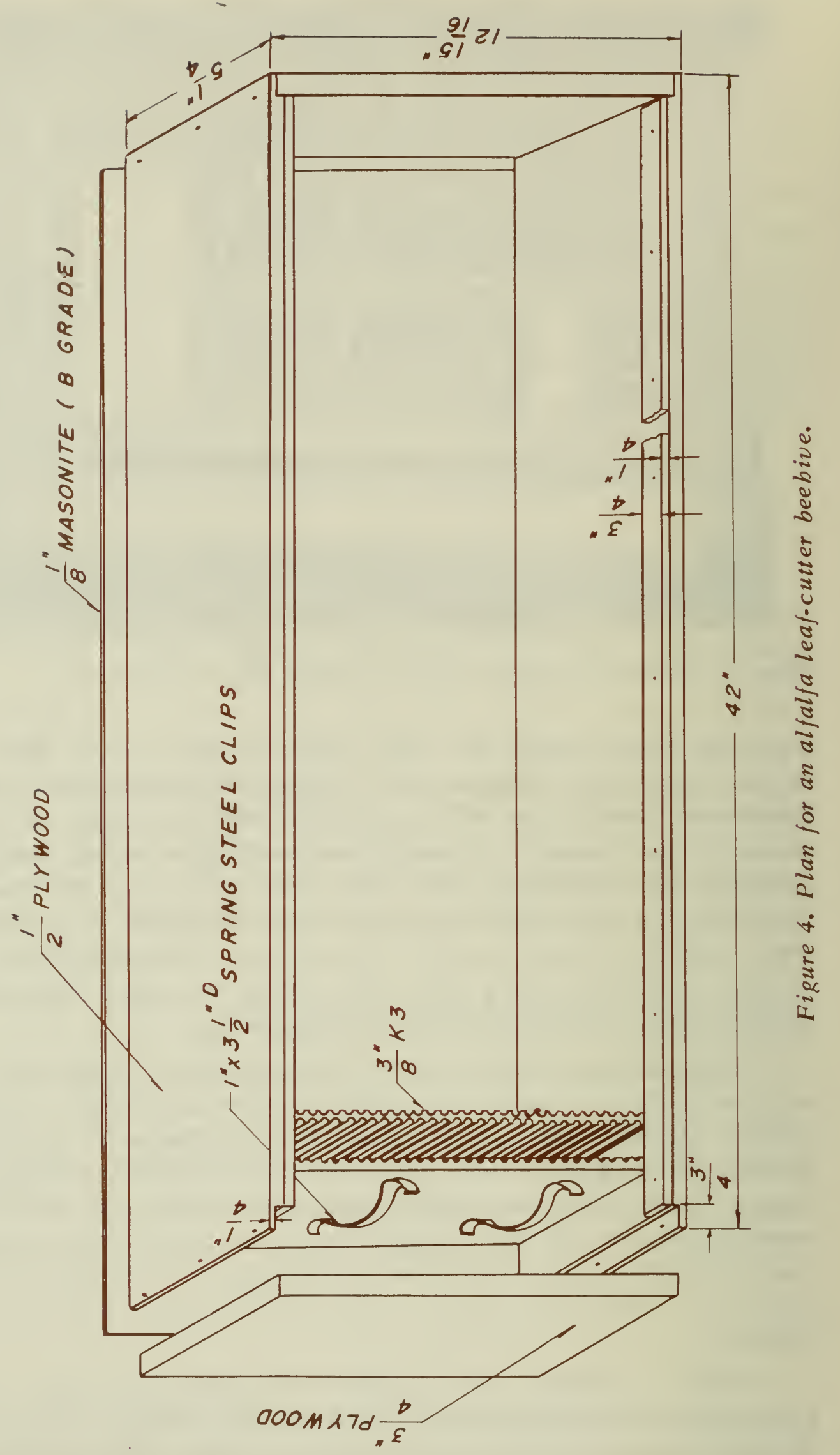


roof, one the back, and two half-sheets the sides. In this shelter, hives may be stacked three deep along the back and sides (Figure 3); additional hives may be stacked on boards set lengthwise in the middle of the shelter (Figures 3 and 5). Runners for the incubation trays are attached to the underside of the roof in such a way that birds cannot get in when the incubation trays are in place (Figure 3). Plans are in Figure 5. Paint the outside of all the shelters the same color because one color may be more attractive than another and the bees will migrate to the shelters with the attractive color. Dull red stain is more attractive than green stain and much more attractive than white.

Space the shelters evenly in the crop at the rate of one every 4 acres. Set out at least 40,000 bees per shelter. The number needed to pollinate your crop adequately will vary according to the weather; the more flying time the bees have during the pollinating period, the fewer will be needed. The bees will go no farther for food than is necessary. You will know that you have adequate numbers of bees when the areas of pollination around the shelters meet. We do not know how many are needed to pollinate a crop as quickly and thoroughly as possible; you may need as many as 40,000 per acre. In southwestern Idaho it has been reported that alfalfa seed fields can be pollinated thoroughly in 3 weeks with about 40,000 bees per acre, but then the hives must be moved to another field or the bees will not have enough food.

Face the shelters east.

Cultivate a 6-foot wide L-shaped patch of ground on the east and south sides of each shelter. The bees often sun themselves on the bare ground to absorb heat, so keep this patch of earth bare during the flying period.

Watch for drift. Bees will often move from shelters in the field to ones near the edges. If the bees drift, move hives from shelters with few bees to shelters with too many.

\section{Incubation Trays}

Incubation trays are designed to hold as many cells as possible and to fit into incubators and beneath shelter roofs, both made of 8-by 4-foot sheets of Aspenite (Figures 3 and 5). Do not pile the cells more than about four deep because the emerging bees may chew into the cells above them. Fit the lids well to prevent the bees from .escaping. Use metal or heavy plastic screening-bees can chew through fiber glass. Plans are in Figure 5. 


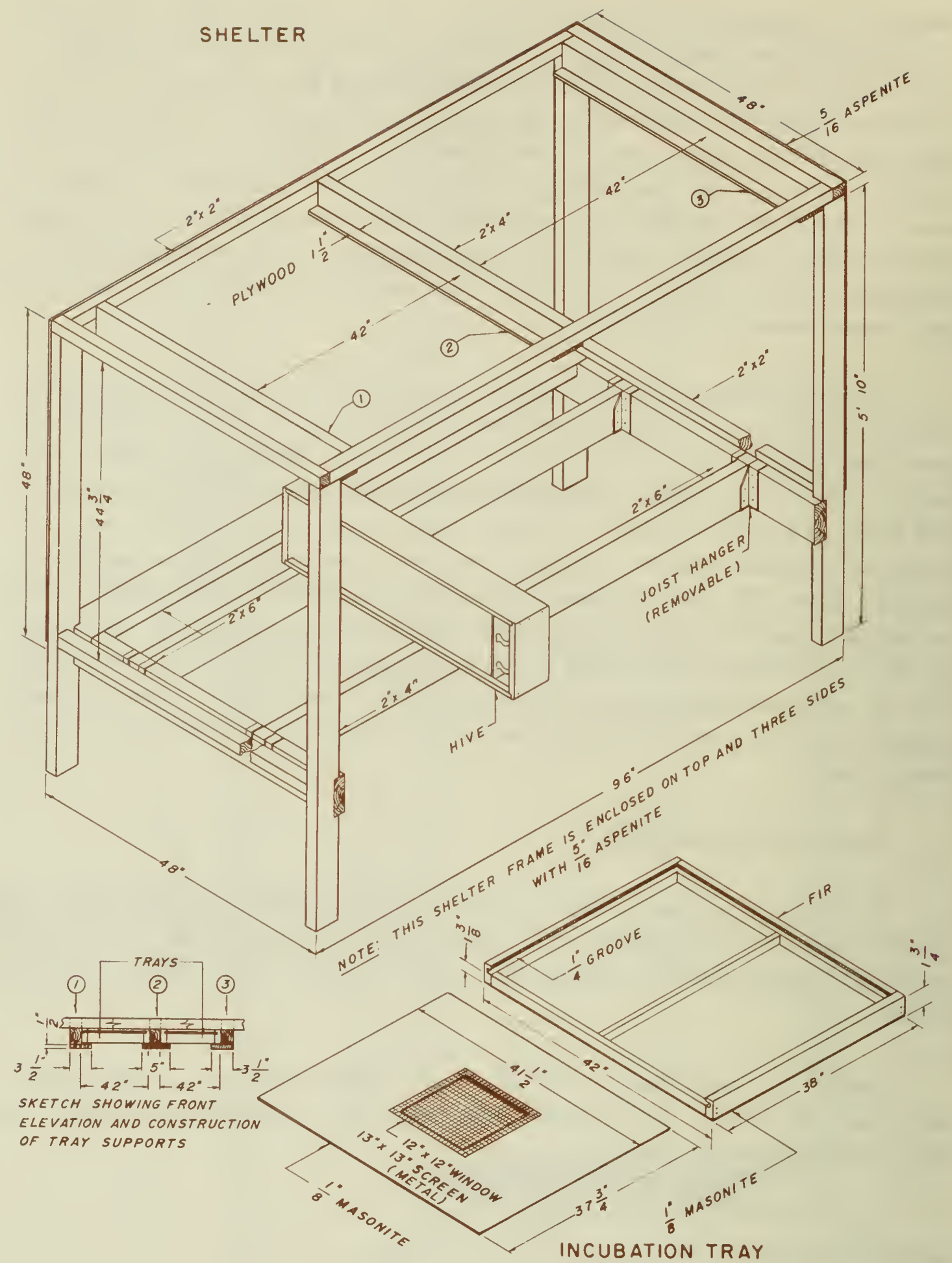

Figure 5. Plans for an alfalfa leaf-cutter bee shelter (top) and incubation tray (bottom). 


\section{Incubators}

An incubator is probably your most important piece of equipment. You may destroy thousands of dollars worth of bees if you do not make and equip it properly. Equip your incubator with a reliable thermostat, heating unit, and fan. You will be incubating at about $85^{\circ} \mathrm{F}$. Temperatures above $90^{\circ}$ hinder development and cause death, so you must have a system that prevents wide fluctuations in temperature. A thermostat with a range of about $35^{\circ}$ to $100^{\circ} \mathrm{F}$ and an interior car warmer, which is both heater and fan, will provide the right temperature conditions in an 8- by 4 - by 6 -foot incubator. An incubator this size will hold 50 trays and each tray 40,000 cells.

Lights for inside the incubator must be on a separate circuit so that they may be turned on or off without affecting the heating element and fan. The main purpose of lights in an incubator is to attract parasites. The parasites, emerging before the bees begin to emerge, fly to the lights and then fall into pans of water placed beneath them and drown. The water in the pans also provides necessary humidity.

The windows in the top and bottom of each door allow you to check temperatures atboth levels and to examine the pans of water and the heatingcirculating unit without opening the incubator. The swing-aside covers for the windows prevent daylight from distracting the parasites from the inside light traps. Plans are in Figure 6.

\section{Cell Removers}

A cell remover ${ }^{1}$ makes it easy to remove bee cells from the grooved boards. In 12 minutes, two men can open a 3000-nest hive, remove the grooved boards and strip the cells from them, and then replace the boards and strips of wood that hold them in the hive. After each grooved board has been pushed past the dowels by the next, it drops on to the curved aluminum slide. If an empty hive is positioned properly at the end of the slide, the boards stack automatically until the pile beneath the slide becomes as high as the bottom of the slide. If the hive could be slowly lowered in this position, all the grooved boards in it would stack automatically. Paint each part with urethane before assembling and repaint after assembling so that the dowels will be protected from wear and the whole unit may be decontaminated easily. It can be steam-cleaned with the apparatus used to clean gasoline motors. Plans are in Figure 7.

\footnotetext{
${ }^{1}$ Invented by W. O. Nummi, Research Station, Lethbridge, Alberta.
} 


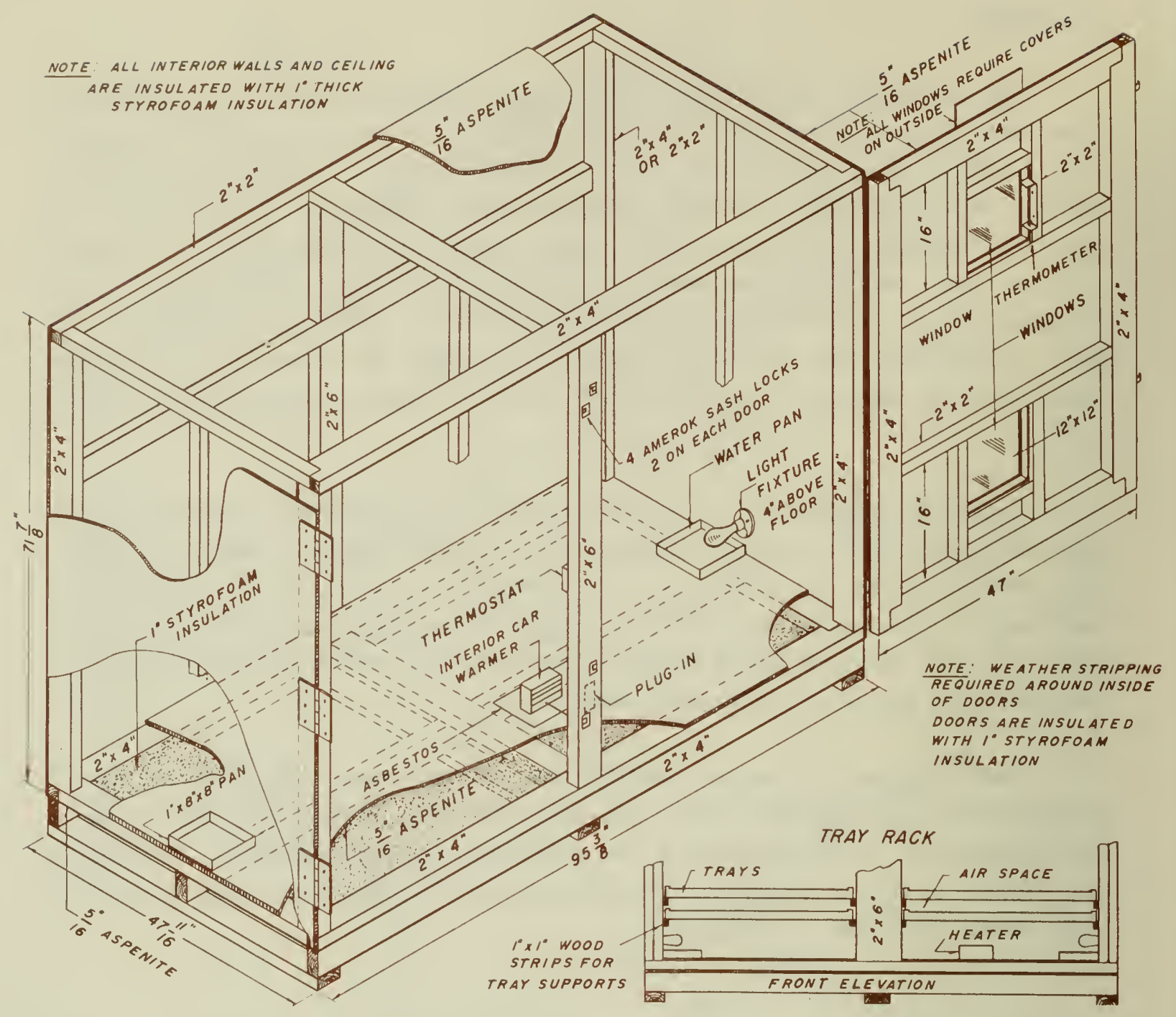

Figure 6. Plan for an alfalfa leaf-cutter bee incubator.

\section{ANNUAL ROUTINE}

Here is a satisfactory, tested method for managing large numbers of bees.

\section{Twenty Days Before the Alfalfa Begins to Bloom}

Remuve the sealed containers from the $40^{\circ} \mathrm{F}$ storage room and spread the cells out in the shallow incubation trays-one cell for every nest in the hives in a shelter. Because some bees die in the cells and half of those that emerge are males, fewer than half as many females as there are tunnels will survive. However, each female can fill two or three tunnels with cells during the nesting season, if the weather is warm. 


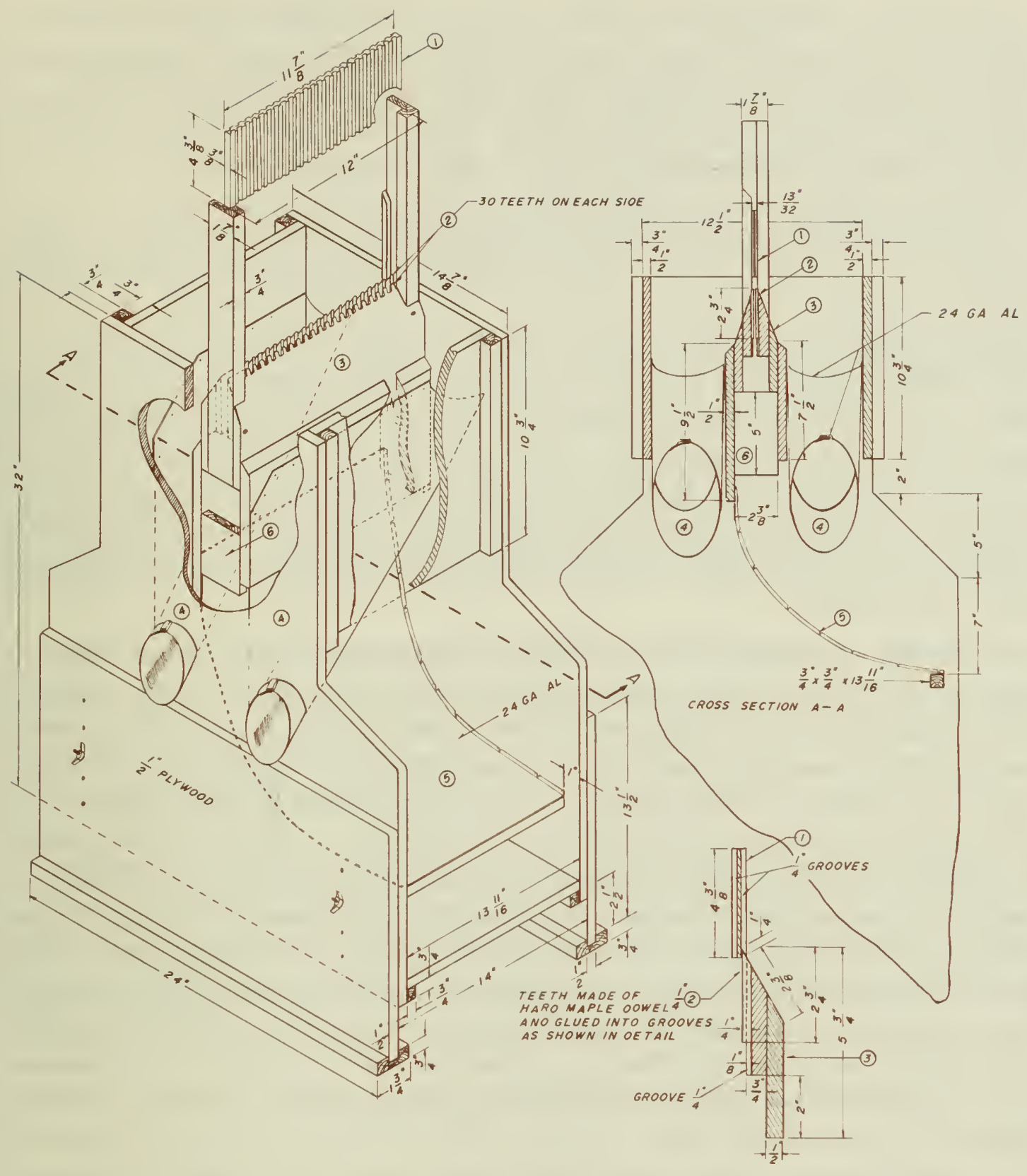

Figure 7. Plan for an alfalfa le af-cutter bee remover.

Put the trays of cells, without lids, on the shelves in the incubator. Set the thermostat at $85^{\circ} \mathrm{F}$. Place shallow pans of water beneath the lights and turn on the lights. Add water to the pans every 2 or 3 days.

To check the progress of your bees in the incubator, remove about 50 larvae from their cocoons and place them in a clean dish. Cut the head ends off the cocoons with a razor blade or fine scissors. Put a pane of glass over the dish and set it in front of a window in the incubator. When the larvae in the cells change to pupae, the eyes change from white to pink 
to black. Then the pupae turn gray and later shed their skins and become adults. If the cocoons have several small larvae in each instead of one big one, these are parasites. Put them in the dish too so that you will know when they emerge. Destroy the parasites in the dish when they become adults, or they will mate and lay eggs on the developing bees.

The first insects to emerge may be parasites, native bees, or wasps. Because these native North American insects develop much more rapidly than the introduced alfalfa leaf-cutter bee, they emerge sooner. They will probably begin to emerge about the 10th day. They will fly to the lights and then drown in the water in the pans below. If any parasites are still alive when you are ready to take the trays to the field, cool the trays to about $55^{\circ} \mathrm{F}$ and remove the parasites; the bees cannot walk or fly at this temperature. If you put a little detergent in the water, the parasites will sink to the bottom quickly. If parasitism is heavy, the parasites in untreated water may form a floating island from which others attracted to the lights may land and take off to reparasitize.

Usually the bees will not begin to emerge until the larvae have incubated for 18 days. But after about 12 days, check the cells regularly for emergence. Put the lids on the trays after the first few bees (males) emerge. Make sure that the lids are on tight. Turn off the lights and in. cubate for another 3 days before setting out the trays in the shelters in the field. About 40 percent of the bees should have emerged by the end of the third day; almost all will be males. The bees emerge more slowly in the field than in the incubator because the temperature is lower. If you do not incubate them for as long as possible before setting them out, many of the females may not emerge in time to complete nest building and pollinate alfalfa soon enough for seed to mature before frost. Alfalfa produces bloom rapidly after the first flowers appear. To make full use of the females, you must have them all out and working by the time the alfalfa is in full bloom.

Take the trays to the field; slide them beneath the roofs of the shelters on the runners provided, and remove the lids. If the weather is warm, some of the emerged bees will leave the trays at once, make short orientation flights, and return. If it is too cool for rapid emergence of the remaining bees, bring in the trays, put the lids back on, and incubate for an additional 48 hours. Repeat this last procedure if, after about 10 days, many of the cocoons are still intact.

\section{After the Bees Are in the Field}

Protect the cells in the trays from mice by putting a tin collar around each leg of the shelter. The white-footed mouse likes to nest in the trays. 
Protect the nests from ants by setting the shelters, when possible, in an irrigated field where ant colonies cannot survive because of flooding. If a shelter must be placed on dry land, watch for predation by ants. If ants attack the bees, search for their nests and sprinkle a little 5 percent granular heptachlor on them. Do not spread the heptachlor haphazardly. The bees are very susceptible to most insecticides. As they often sun themselves on the bare patches of ground near the shelters, they will die if you apply insecticide to these areas.

If an insecticide is used to control a pest in the alfalfa after the bees have been taken to the field, do not use a long-lasting insecticide or one that is highly toxic to bees. If the insecticide is toxic to bees, place the hives in a cool, dark room the night before you apply it. Leave the hives there for several days, depending on the duration of the residual action of the insecticide used, before replacing them in the field. Be sure to replace the hives in their original positions so that you do not confuse the bees.

Watch for drift. Bees will often move from shelters in the field to shelters closer to the edge. You cannot induce the bees to return to their former shelter by moving the newly occupied hives to the deserted shelter. Supply them instead with enough nests in the field by moving empty hives from the shelters that have few bees.

The bees may drift from shelters to nearby shingle-covered buildings. If you notice bees hovering near shingles on the vertical sides of a building, take a bive in which the bees have nested previously and place it against the side of the building; a hive that has been used before and has the smell of bees on it will be much more attractive than a new one.

Continue to check regularly for predation by birds or animals, and for overcrowding. If birds are causing damage, cover the fronts of the shelters with chicken wire. If mice are troublesome, repair or modify the metal sheaths around the legs of the shelter. If the bees are overcrowded, bring in more empty hives; make room for the new hives by moving out the ones that are already filled with cells. The hives are overcrowed when there is debris containing live larvae on the shelves below the hives. This indicates that bees are removing the contents of tunnels in order to nest.

\section{About Two Months Later}

Remove the bives when almost all the bees have finsibed nesting or by August 20, whichever comes first. If the weather has been warm and dry for 2 weeks before the hives are removed, place them in a dry, unheated 
storage room. If the weather has been cold or if rain has dampened the the cells in the nests sometime during the previous 2 weeks, place the hives in a warm, dry room for about 2 weeks to allow the cells to dry and the late larvae to finish feeding and spin their cocoons. Then place the hives in the dry, unheated room. A few second-generation adults may emerge after the hives are placed in the warm room. Because the bees overwinter only as mature larvae, the ones that emerge shortly after the hives are brought in have already passed the larval stage and they cannot survive the winter.

\section{During the Fall and Winter}

Remove the cells from the nests and prepare them for winter storage before temperatures in the unheated room drop below $0^{\circ} \mathrm{F}$. Dry cells can be removed much more easily than damp ones. If you have a lot of bees, a cell remover (see Figure 7 and page 13) will speed up cell removal 60-fold (from boards having 30 grooves on either side). Otherwise, you may gently roll the cells out with your fingers or slice them out with a narrowbladed putty knife or similar instrument.

Allow damp cells to dry for a few days. When they are dry, remove the debris by shaking and gently rubbing them over a screen. An oat screen from a seed cleaner with 9/64- by 3/4-inch openings is especially good because the holes in it are long, narrow, and rounded on the ends.

Put the cells in polyethylene bags. Seal the bags tightly and store them at about $40^{\circ} \mathrm{F}$ in a room where there are no mice.

If you store the cells in a damp root cellar, be careful to seal the bags tightly. Otherwise, the cells will take up moisture and become moldy.

If mold develops, remove the cells and soak them in a solution of equal parts of water and household bleach for 5 minutes. Then dust the cells with 50 or 65 percent captan and spread them out to dry in a cool, dry room. When they are dry, seal them in a clean polyethylene bag and return them to cold storage.

Replace the grooved boards in the hive as you remove the cells. If mold is present, mark the hive and set it aside to be decontaminated. To decontaminate, remove the boards and strap them loosely in two equal bundles, after first putting a piece of 3/4-inch plywood (the same length and width as a grooved board) at the ends of each bundle. You must do this with Particleboard because it swells greatly when it is wet. Then steam-clean 
the nests with equipment and materials used to clean gasoline motors. Apply the steam once from each side. Clean the inside of the contaminated hive. Dry the bundles of nests and the hive on a flat surface so that they will not warp.

Prepare the hives and shelters for next season. To determine the number of nests needed, measure the total bulk of screened cells and then sample several known portions to find out how many cells contain cocoons in each portion. Multiply the average number of cocoons in a portion by the total number of portions. Sample the cells by rolling each cell gently between your thumb and forefinger. If the cocoon is not complete, the cell will collapse or the circular leaf cuttings forming the cap will pop out. If the weather during the pollinating period is good and the bees are able to finish building their nests, you will need a nest (tunnel) for every cell incubated.

\section{MORE INFORMATION}

As this bulletin is being written, edited, and printed, many plans for testing new ideas and equipment are being made. By the time it reaches you, certain more efficient procedures and equipment may have been devised. If we waited until all questions were answered, the bulletin would never be written. Keep in close touch with us at the Research Station, Lethbridge, and with entomologists and growers in other regions who are well acquainted with the alfalfa leaf-cutter bee. 


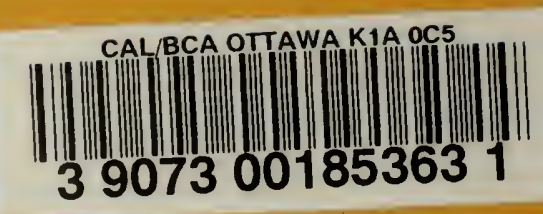

Copies of this publication may be obtained from:

\title{
INFORMATION DIVISION \\ CANADA DEPARTMENT OF AGRICULTURE \\ OTTAWA
}

\author{
First printed as Importing and man- \\ aging the Alfalfa Leaf-cutter Bee, \\ Publication 1209 ...................... 1965 \\ Revised as Publication $1313 \ldots 1967$
}

